Short communication

\title{
Lattice Enthalpies of Lanthanide Orthoferrites $\mathrm{LnFeO}_{3}$
}

\author{
Dimitar Petrov
}

\author{
Department of Physical Chemistry, Plovdiv University, 24, Tsar Asen Str., 4000 Plovdiv, Bulgaria \\ * Corresponding author: E-mail: petrov_d_n@abv.bg \\ Tel: +35 932 261206; fax: +35932261403
}

Received: 27-11-2014

\begin{abstract}
Lattice enthalpies $\Delta_{\mathrm{L}} \mathrm{H}^{\Theta}$ of lanthanide orthoferrites, $\mathrm{LnFeO}_{3}$ have been determined by the Born-Haber cycle and compared with those calculated by an empirical equation. Enthalpies of formation of $\mathrm{LnFeO}_{3}$ from two different sources have been employed: from oxides $\left(\mathrm{Ln}_{2} \mathrm{O}_{3}, \mathrm{Fe}_{2} \mathrm{O}_{3}\right)$, for $12 \mathrm{LnFeO}_{3}$, and from elements, for $8 \mathrm{LnFeO}_{3}$, but the differences in $\Delta_{\mathrm{L}} \mathrm{H}^{\Theta}$ are very small. The Born-Haber cycle in both routes results in close values of $\Delta_{\mathrm{L}} \mathrm{H}^{\Theta}$ to those obtained by the empirical equation of Glasser and Jenkins. A correspondence in dimension and magnitude has been found between the partial derivative of the lattice enthalpies to the molar volumes and an upper limit of the shear moduli of the lanthanide orthoferrites.
\end{abstract}

Keywords: Lattice enthalpies; lanthanide orthoferrites; shear moduli; Born-Haber cycle

\section{Introduction}

Lanthanide orthoferrites, $\mathrm{LnFeO}_{3}$ are members of the perovskites group $\mathrm{ABX}_{3}$ and crystallize in an orthorhombic structure of space group Pbnm (No.62); each unit cell comprises four molecules $(z=4)$ with lanthanide and iron sites equivalent in symmetry. ${ }^{1}$ Lanthanide orthoferrites, $\mathrm{LnFeO}_{3}$ are among the most studied lanthanide solids. The continuing research interest is stimulated by a number of applications based on their valuable properties: magnetic, magneto-optical, sensing, catalytic, electrical, thermochemical, etc.

The magnetic properties of hydrothermally grown single-phase $\mathrm{LnFeO}_{3}$ with all lanthanides $\mathrm{Ln}$, except $\mathrm{Ce}$ and $\mathrm{Pm}$, have been investigated recently and related to the $\mathrm{Ln}^{3+}$ ionic radii. ${ }^{2}$ Spontaneous magnetostriction and thermal expansibility have been found in $\mathrm{TmFeO}_{3}$ at low temperatures, ${ }^{3}$ while $\mathrm{SmFeO}_{3}$ exhibits temperature-induced magnetization reversal below the critical low temperature. ${ }^{4}$ Low-temperature magnetic phase transitions in $\mathrm{HoFe}$ $\mathrm{O}_{3}$ have been related to heat-capacity anomalies. ${ }^{5}$

Thick films of p-type semiconducting $\mathrm{LnFeO}_{3}, \mathrm{Ln}=$ $\mathrm{La}$ or lanthanides from Pr to $\mathrm{Lu}$, except Pm, have been prepared by polyol synthesis and tested in respect to gas sensing. ${ }^{6}$ Lanthanide orthoferrites, $\mathrm{LnFeO}_{3}, \mathrm{Ln}=\mathrm{Sm}, \mathrm{Nd}$, $\mathrm{Gd}$, have been synthesized as nanoparticles with size less than $150 \mathrm{~nm},{ }^{7}$ as ceramic fibres with $\mathrm{Ln}=\mathrm{La}, \mathrm{Sm}, \mathrm{Gd}$, Dy, $\mathrm{Er}, \mathrm{Yb}^{8}$ or from molten $\mathrm{NaOH}$ flux with $\mathrm{Ln}=\mathrm{La}, \mathrm{Pr}, \mathrm{Nd} .{ }^{9}$
$\mathrm{LnFeO}_{3}$ have been found effective as pigments, with $\mathrm{Ln}=\mathrm{La}, \mathrm{Gd}, \mathrm{Tm}, \mathrm{Yb}, \mathrm{Lu},{ }^{10}$ or as nanosize catalysts $(\mathrm{Ln}=$ $\mathrm{La}, \mathrm{Sm}$ ) in the photodegradation of rhodamine B under visible light. ${ }^{11}$ Pressure and gamma sensing properties of substituted orthoferrites, $\mathrm{Ln}_{0.7} \mathrm{Ca}_{0.3} \mathrm{FeO}_{3}(\mathrm{Ln}=\mathrm{La}, \mathrm{Gd}$, Dy, $\mathrm{Y}, \mathrm{Er}$ ) have been related to dc/ac resistivity and magnetic susceptibility. ${ }^{12}$ Recent study of polycrystalline Mn-doped $\mathrm{PrFeO}_{3}$ has been directed to structural, optical and dielectric properties. ${ }^{13}$

While the studies of the abovementioned properties are extensive and large in number, those on the thermodynamic properties are rare and do not cover the entire lanthanide series of orthoferrites. For example, nine thermodynamic functions have been generated from differential scanning calorimetry and solid-state electrochemical cells of $\mathrm{LnFeO}_{3}(\mathrm{Ln}=\mathrm{Nd}, \mathrm{Sm}, \mathrm{Eu}, \mathrm{Gd}, \mathrm{Tb}, \mathrm{Dy}, \mathrm{Ho}$, Er). ${ }^{14,15}$ The changes of the standard enthalpies of formation (CSE) for twelve $\mathrm{LnFeO}_{3}$, excluding those of $\mathrm{Ce}$ and $\mathrm{Pm}$, and four reactions pertaining to the stability of lanthanide perovskites have been discussed on the basis of hightemperature $(977 \mathrm{~K})$ calorimetry using $2 \mathrm{PbO} \mathrm{B}_{2} \mathrm{O}_{3}$ flux. ${ }^{16}$

Various authors relate different energy characteristics of lanthanide orthoferrites to structural stability and physical properties. The standard free-energy change $\Delta_{\mathrm{r}} \mathrm{G}^{\theta}$ for the reaction of formation of $\mathrm{LnFeO}_{3}$ has been related to the Madelung energy; ${ }^{17}$ ab initio calculated energy differences for $\mathrm{LnFeO}_{3}$ have been assigned to the antiferromagnetic and ferromagnetic alignments between the iron 
ions ${ }^{18}$ it has been observed a dependence between $\mathrm{M}-\mathrm{O}$ bond energies and gas sensitivity of $\operatorname{LnMO}_{3}(\mathrm{M}=\mathrm{Cr}, \mathrm{Fe}){ }^{6}$

The energetics of the lanthanide orthoferrites is important for their systematic studies, including thermodynamic stability. The amount of molar energy binding the ions in the crystalline $\mathrm{LnFeO}_{3}$ is a basic quantity for this series of compounds. In this paper we follow our research interest in the lattice enthalpies of various groups of lanthanide compounds, namely: $\mathrm{LnAlO}_{3},{ }^{19} \mathrm{Ln}_{3} \mathrm{Ga}_{5} \mathrm{O}_{12},{ }^{20} \mathrm{Ln}$ $\mathrm{VO}_{4}{ }^{21}$ and $\mathrm{LnPO}_{4}{ }^{22}$ The purpose of this work is to determine the lattice energies of $\mathrm{LnFeO}_{3}$ by the Born-Haber cycle and to relate the results to certain mechanical properties.

\section{Method}

The lanthanide orthoferrites, $\mathrm{LnFeO}_{3}$ exhibit a defined stoichiometry and it is assumed that the lattice is built up of ions with integral charges. Hence, the lattice enthalpies $\Delta_{\mathrm{L}} \mathrm{H}^{\theta}$ can be determined by the Born-Haber cycle expressed in Eq. (1) below. The term A corresponds to two different CSE of formation of $\mathrm{LnFeO}_{3}$ - either from oxides or from elements (Eq. (2)):

$$
\begin{aligned}
& \mathrm{A}+\Delta_{\mathrm{s}} \mathrm{H}^{\Theta}(\mathrm{Ln})+\Delta_{\mathrm{s}} \mathrm{H}^{\Theta}(\mathrm{Fe})+(3 / 2) \Delta_{\mathrm{d}} \mathrm{H}^{\Theta}(\mathrm{O}-\mathrm{O})+ \\
& +\Delta_{\mathrm{i}} \mathrm{H}^{\Theta}(\mathrm{Ln})+\Delta_{\mathrm{i}} \mathrm{H}^{\Theta}(\mathrm{Fe})+3 \Delta_{\mathrm{eg}} \mathrm{H}^{\Theta}(\mathrm{O})- \\
& \left.-\Delta_{\mathrm{L}} \mathrm{H}^{\Theta}(\operatorname{LnFeO})_{3}\right)=0, \\
& \mathrm{~A}=\left[-\Delta_{\mathrm{f} \text { ox }} \mathrm{H}^{\Theta}\left(\mathrm{LnFeO}_{3}\right)-(1 / 2) \Delta_{\mathrm{f}} \mathrm{H}^{\Theta}\left(\mathrm{Ln}_{2} \mathrm{O}_{3}\right)-\right. \\
& \left.(1 / 2) \Delta_{\mathrm{f}} \mathrm{H}^{\Theta}\left(\mathrm{Fe}_{2} \mathrm{O}_{3}\right)\right], \\
& \text { or } \mathrm{A}=\left[-\Delta_{\mathrm{f}, \mathrm{el}} \mathrm{H}^{\Theta}\left(\mathrm{LnFeO}_{3}\right)\right],
\end{aligned}
$$

where the notation is as follows: $:^{23}$ the left-hand side subscript to each enthalpy refers to, respectively: L-lattice, f-formation, f,el-formation from elements, f,ox-formation from oxides, s-sublimation, i-ionization, d-dissociation, and eg-electron gain; the superscript $\left({ }^{\boldsymbol{\theta}}\right)$ designates "standard conditions": temperature $\mathrm{T}=298.15 \mathrm{~K}$, pressure $\mathrm{P}=$ $101325 \mathrm{~Pa}$. The CSE are related to the corresponding energies of dissociation, electron gain, ionization, subli- mation, and potential energy of the lattice according to the formulae, respectively:

$$
\begin{aligned}
& \Delta_{\mathrm{d}} \mathrm{H}^{\Theta}=-\Delta_{\mathrm{d}} \mathrm{U}^{\Theta}-(5 / 2) \mathrm{RT}, \Delta_{\mathrm{eg}} \mathrm{H}^{\Theta}= \\
& =\Delta_{\mathrm{eg}} \mathrm{U}^{\Theta}-5 \mathrm{RT}, \Delta_{\mathrm{i}} \mathrm{H}^{\Theta}=\Delta_{\mathrm{i}} \mathrm{U}^{\Theta}+3(5 / 2) \mathrm{RT} \\
& \Delta_{\mathrm{s}} \mathrm{H}^{\Theta}=\Delta_{\mathrm{s}} \mathrm{U}^{\Theta}+(5 / 2) \mathrm{RT} \\
& \mathrm{LnFeO}_{3}(\mathrm{~s}) \rightarrow \mathrm{Ln}^{3+}(\mathrm{g})+\mathrm{Fe}^{3+}(\mathrm{g})+ \\
& +3 \mathrm{O}^{2-}(\mathrm{g}), \Delta \mathrm{n}(\mathrm{g})=+5 \mathrm{~mol} ; \Delta_{\mathrm{L}} \mathrm{H}^{\Theta}= \\
& =-\Delta_{\mathrm{L}} \mathrm{U}^{\Theta}-3 \mathrm{RT} .
\end{aligned}
$$

The necessary data for the calculation of $\Delta_{\mathrm{L}} \mathrm{H}^{\Theta}$ are presented in Table 2 and Table 3. The equation for each step (physical or chemical change) of the cycle is presented in Table 1. The sign of each CSE must be reversed if the actual process takes place in the opposite direction. The sum of all CSE is equal to zero for a closed route of changes starting and ending at one and the same state. Here, the final process is the formation of lanthanide orhoferrites in solid phase, $\mathrm{LnFeO}_{3}(\mathrm{~s})$, from ions in gas phase. This step is reverse to that one in the definition of lattice energy as displayed in Eq. (5).

\section{Results and Discussion}

The lattice enthalpies obtained in this work are presented in Table 4. The values of $\Delta_{\mathrm{L}} \mathrm{H}^{\theta}$ of lanthanide orhoferrite lattice determined by the Born-Haber thermochemical cycle vary slightly, 2.1 or $2.4 \%$ within the lanthani-

\begin{tabular}{|c|c|c|}
\hline No & Equation of the process in each step & $\Delta \mathbf{H}^{\theta}$ \\
\hline (1a. & $\mathrm{LnFeO}_{3}(\mathrm{~s}) \rightarrow(1 / 2) \mathrm{Ln}_{2} \mathrm{O}_{3}(\mathrm{~s})+(1 / 2) \mathrm{Fe}_{2} \mathrm{O}_{3}(\mathrm{~s})$ & $-\Delta_{\mathrm{f}, \mathrm{ox}} \mathrm{H}^{\Theta}$ \\
\hline $1 \mathrm{~b}$. & $(1 / 2) \operatorname{Ln}_{2} \mathrm{O}_{3}(\mathrm{~s})+(1 / 2) \mathrm{Fe}_{2} \mathrm{O}_{3}(\mathrm{~s}) \rightarrow \mathrm{Ln}(\mathrm{s})+\mathrm{Fe}(\mathrm{s})+(3 / 2) \mathrm{O}_{2}(\mathrm{~g})$ & $-(1 / 2) \Delta_{\mathrm{f}} \mathrm{H}^{\Theta}$ \\
\hline 1. & $\mathrm{LnFeO}_{3}(\mathrm{~s}) \rightarrow \mathrm{Ln}(\mathrm{s})+\mathrm{Fe}(\mathrm{s})+(3 / 2) \mathrm{O}_{2}(\mathrm{~g})$ & $-\Delta_{\mathrm{f}, \mathrm{el}} \mathrm{H}^{\theta}$ \\
\hline 2. & $\mathrm{Ln}(\mathrm{s})+\mathrm{Fe}(\mathrm{s})+(3 / 2) \mathrm{O}_{2}(\mathrm{~g}) \rightarrow \mathrm{Ln}(\mathrm{g})+\mathrm{Fe}(\mathrm{s})+(3 / 2) \mathrm{O}_{2}(\mathrm{~g})$ & $\Delta_{s} \mathrm{H}^{\Theta}(\operatorname{Ln})$ \\
\hline 3. & $\mathrm{Ln}(\mathrm{g})+\mathrm{Fe}(\mathrm{s})+(3 / 2) \mathrm{O}_{2}(\mathrm{~g}) \rightarrow \mathrm{Ln}(\mathrm{g})+\mathrm{Fe}(\mathrm{g})+(3 / 2) \mathrm{O}_{2}(\mathrm{~g})$ & $\Delta_{\mathrm{s}} \mathrm{H}^{\Theta}(\mathrm{Fe})$ \\
\hline 4. & $\mathrm{Ln}(\mathrm{g})+\mathrm{Fe}(\mathrm{g})+(3 / 2) \mathrm{O}_{2}(\mathrm{~g}) \rightarrow \mathrm{Ln}(\mathrm{g})+\mathrm{Fe}(\mathrm{g})+3 \mathrm{O}(\mathrm{g})$ & $(3 / 2) \Delta_{\mathrm{d}} \mathrm{H}^{\Theta}\left(\mathrm{O}_{2}\right)$ \\
\hline 5. & $\mathrm{Ln}(\mathrm{g})+\mathrm{Fe}(\mathrm{g})+3 \mathrm{O}(\mathrm{g}) \rightarrow \mathrm{Ln}^{3+}(\mathrm{g})+3 \mathrm{e}^{-}+\mathrm{Fe}(\mathrm{g})+3 \mathrm{O}(\mathrm{g})$ & $\Delta_{i} \mathrm{H}^{\Theta}(\operatorname{Ln})$ \\
\hline 6. & $\mathrm{Ln}^{3+}(\mathrm{g})+3 \mathrm{e}^{-}+\mathrm{Fe}(\mathrm{g})+3 \mathrm{O}(\mathrm{g}) \rightarrow \mathrm{Ln}^{3+}(\mathrm{g})+3 \mathrm{e}^{-}+\mathrm{Fe}^{3+}(\mathrm{g})+3 \mathrm{e}^{-}+3 \mathrm{O}(\mathrm{g})$ & $\Delta_{\mathrm{i}} \mathrm{H}^{\Theta}(\mathrm{Fe})$ \\
\hline 7. & $\mathrm{Ln}^{3+}(\mathrm{g})+\mathrm{Fe}^{3+}(\mathrm{g})+3 \mathrm{O}(\mathrm{g})+6 \mathrm{e}^{-} \rightarrow \mathrm{Ln}^{3+}(\mathrm{g})+\mathrm{Fe}^{3+}(\mathrm{g})+3 \mathrm{O}^{2-}(\mathrm{g})$ & $3 \Delta_{\mathrm{eg}} \mathrm{H}^{\mathrm{\theta}}(\mathrm{O})$ \\
\hline 8. & $\mathrm{Ln}^{3+}(\mathrm{g})+\mathrm{Fe}^{3+}(\mathrm{g})+3 \mathrm{O}^{2-}(\mathrm{g}) \rightarrow \mathrm{LnFeO}_{3}(\mathrm{~s})$ & $-\Delta_{L} H^{\Theta}$ \\
\hline
\end{tabular}
de series to the mean value, respectively for those determined with CSE of formation of $\mathrm{LnFeO}_{3}$ from elements or from oxides.

The Born - Haber cycle displayed in Table 1 begins with either steps $1 \mathrm{a}$ and $1 \mathrm{~b}$ (reverse process of the formation of $\mathrm{LnFeO}_{3}$ from oxides) or with step 1 (reverse process of the formation of $\mathrm{LnFeO}_{3}$ from elements) and then to proceed via steps 2 to 8 . The reported values of $\Delta_{\text {f, ox }} \mathrm{H}^{\theta}$ ${ }^{16}$ have been used in the first route and of $\Delta_{\mathrm{f}, \mathrm{el}} \mathrm{H}^{\Theta}{ }^{15}$ in the second one.

Table 1. Born - Haber cycle for lanthanide orthoferrites, $\mathrm{LnFeO}_{3}$

Petrov: Lattice Enthalpies of Lanthanide Orthoferrites $\mathrm{LnFeO}_{3}$ 
The range of $\Delta_{\mathrm{L}} \mathrm{H}^{\Theta}$ variation is small since the formation of $\mathrm{LnFeO}_{3}$ is determined mainly by the change of $\mathrm{Ln}^{3+}$ ionic radii appropriate to the perovskite structure, i.e. by the ionic $\mathrm{Ln}-\mathrm{O}$ bonds. The accuracies of determination of $\Delta_{\mathrm{L}} \mathrm{H}^{\theta}$ have been evaluated with the accuracies of the quantities as included in Eq. (1) where available. Because of the lack of standard deviations for certain quantities in Table 2 and Table 3, the r.m.s. deviations of $\Delta_{\mathrm{L}} \mathrm{H}^{\Theta}$ determined in the present work should be considered minimal ones and not lower than $0.2 \%$ of the respective value. The r.m.s. deviations of $\Delta_{\mathrm{L}} \mathrm{H}^{\Theta}$ obtained from $\Delta_{\text {f,el }} \mathrm{H}^{\Theta}$ are smaller because of the smaller number of terms included in the summation, Eqs. (1) and (2).

Table 2. Standard enthalpy changes of iron and oxygen

\begin{tabular}{|c|c|c|}
\hline$\overline{\Delta \mathbf{H}^{\Theta} / \mathrm{kJ} \mathrm{mol}^{-1}}$ & Value & Ref. \\
\hline$\overline{\Delta, \mathrm{H}^{\Theta}(\mathrm{Fe})}$ & $5300.4 \pm 0.1$ & [24] \\
\hline$\Delta_{\mathrm{f}} \mathrm{H}^{\Theta}\left(\mathrm{Fe}_{2} \mathrm{O}_{3}\right)$ & -824.2 & [24] \\
\hline$\Delta \mathrm{H}^{\Theta}(\mathrm{Fe})$ & $398.6 \pm 0.1$ & [25] \\
\hline$\Delta_{\mathrm{d}}^{\mathrm{s}} \mathrm{H}^{\Theta}\left(\mathrm{O}_{2}\right)$ & $498.36 \pm 0.17$ & [24] \\
\hline$\Delta \mathrm{H}^{\theta}(\mathrm{O})$ & 715.4 & [23] \\
\hline
\end{tabular}

$\Delta_{\mathrm{L}} \mathrm{H}^{\Theta}$ determined here are compared in Table 4 with an empirical equation for lattice potential energy $\Delta_{\mathrm{L}} \mathrm{U}$, i.e. $\mathrm{U}_{\text {POT }}{ }^{26}$. The equation is as follows:

$$
U_{P O T}=A I\left(\frac{2 I}{v_{m}}\right)^{1 / 3}
$$

where $\mathrm{A}=121.39 \mathrm{~kJ} \mathrm{~mol}^{-1} \mathrm{~nm}$ (an electrostatic factor), $\mathrm{I}=$ $1 / 2 \sum n_{i} z_{i}^{2}$ is the ionic strength with $n_{i}$ being the number of ions with charge $\mathrm{z}_{\mathrm{i}}$ per formula, $\mathrm{I}=15$ for $\mathrm{LnFeO}_{3}$, and $\mathrm{v}_{\mathrm{m}}$ is the molecular volume in $\mathrm{nm}^{3}$; the corresponding values of $\mathrm{v}_{\mathrm{m}}$ are given in Table 4 .
According to Eq. (5), the quantities $\Delta_{\mathrm{L}} \mathrm{H}^{\Theta}$ and $\Delta_{\mathrm{L}} \mathrm{U}$ are related by factor proportional to $\mathrm{RT}=2.48 \mathrm{~kJ} \mathrm{~mol}^{-1}$ at $\mathrm{T}=298.15 \mathrm{~K}$, or by $7.44 \mathrm{~kJ} \mathrm{~mol}^{-1}$ with the inclusion of the zero-point energy. ${ }^{27}$ This value presents about $0.05 \%$ of the value of $\Delta_{\mathrm{L}} \mathrm{H}^{\Theta}$.

The values in the last column of Table 4 determined by Eq. (6) are about $4 \%$ lower than those yielded by the Born - Haber cycle. It has been commented that the empirical formula (6) should yield estimates within $\pm 7 \%$ compared to the known values. ${ }^{26}$

It should be noted that the $\Delta_{\mathrm{L}} \mathrm{H}^{\Theta}$ values in the present work are obtained from experimental values of CSE included in Eq. (1) and that they do not depend on structural features or mechanisms of summation of pair interactions.

The plot of lattice enthalpies vs. molar volumes of $\mathrm{LnFeO}_{3}$ (with CSE of formation of $\mathrm{LnFeO}_{3}$ from oxides) is presented in Fig. 1. The straight line has a regression coefficient $\mathrm{R}^{2}=0.981$ and a negative slope $\left(\partial \Delta_{\mathrm{L}} \mathrm{H}^{\Theta} / \partial \mathrm{V}_{\mathrm{m}}\right)$ $=-127.0 \times 10^{6} \mathrm{~kJ} \mathrm{~m}^{-3}$, or $\left(\partial \Delta_{\mathrm{L}} \mathrm{H}^{\Theta} / \partial \mathrm{V}_{\mathrm{m}}\right)=-127.0 \times 10^{9}$ $\mathrm{Pa}$. The negative sign of the slope accounts for the trend of changes of lattice enthalpies within the series of 12 lanthanide orthoferrites.

Hence, an upper limit for the shear modulus of Ln$\mathrm{FeO}_{3}, \mathrm{G} \approx 150 \mathrm{GPa}$, has appeared in this case. The molar volumes $\mathrm{V}_{\mathrm{m}}$ of $\mathrm{LnFeO}_{3}$ have been determined here from the reported unit cell volumes. ${ }^{2}$ Taking the molar volume of $\mathrm{PmFeO}_{3}$ as a mean value between those of $\mathrm{NdFeO}_{3}$ and $\mathrm{SmFeO}_{3}, 35.365 \times 10^{-6} \mathrm{~m}^{3} \mathrm{~mol}^{-1}$, the missing lattice enthalpy of $\mathrm{PmFeO}_{3}$ has been found, $\Delta_{\mathrm{L}} \mathrm{H}^{\Theta}=14031 \mathrm{~kJ} \mathrm{~mol}^{-1}$.

The variation of the lattice enthalpies vs. molar volumes of $\mathrm{LnFeO}_{3}$ with CSE of formation of $\mathrm{LnFeO}_{3}$ from elements results in similar straight line with a regression coefficient $\mathrm{R}^{2}=0.9602$ and negative slope, $128.1 \times 10^{9} \mathrm{~Pa}$.

It is important to note that the novelty of the present study is equally based on the lattice enthalpies and on the

Table 3. Standard enthalpy changes of formation of lanthanide orthoferrites and sesquioxides, and of sublimation and ionization of lanthanide metals (all in $\mathrm{kJ} \mathrm{mol}^{-1}$ )

\begin{tabular}{|c|c|c|c|c|c|}
\hline $\mathrm{LnFeO}_{3}$ & $\begin{array}{c}-\Delta_{\mathrm{f}, \mathrm{el}} \mathbf{H}^{\Theta} \\
{[\mathbf{1 5}]}\end{array}$ & $\begin{array}{c}-\Delta_{\mathrm{f}, \mathrm{ox}} \mathrm{H}^{\Theta} \\
{[\mathbf{1 6}]^{\mathrm{a}}}\end{array}$ & $\begin{array}{c}-\Delta_{\mathrm{f}} \mathbf{H}^{\Theta}\left(\operatorname{Ln}_{2} \mathrm{O}_{3}\right) \\
{[24]}\end{array}$ & $\begin{array}{c}\Delta_{\mathrm{s}} H^{\Theta}(\mathrm{Ln}) \\
{[24]}\end{array}$ & $\begin{array}{c}\Delta_{\mathrm{i}} \mathbf{H}^{\Theta}(\mathbf{L n}) \\
{[28]}\end{array}$ \\
\hline $\mathrm{PrFeO}_{3}$ & & 48.53 & 1809.6 & 355.6 & $3646.1 \pm 9.9$ \\
\hline $\mathrm{NdFeO}_{3}$ & 1357.4 & 44.35 & 1807.9 & 327.6 & $3715.8 \pm 38.6$ \\
\hline $\mathrm{SmFeO}_{3}$ & 1355.2 & 44.35 & $1823.0 \pm 3.0$ & 206.7 & $3887.7 \pm 38.6$ \\
\hline $\mathrm{EuFeO}_{3}$ & 1285.6 & 44.35 & $1651.4 \pm 12.1$ & 175.3 & $4054.3 \pm 10.9$ \\
\hline $\mathrm{GdFeO}_{3}$ & 1360.5 & 44.35 & $1819.6 \pm 12.1$ & 397.5 & $3768.1 \pm 19.3$ \\
\hline $\mathrm{TbFeO}_{3}$ & 1372.4 & 40.17 & $1865.2 \pm 7.5$ & 388.7 & $3808.7 \pm 19.3$ \\
\hline $\mathrm{DyFeO}_{3}$ & 1369.4 & 35.98 & $1863.1 \pm 7.5$ & 290.4 & $3916.3 \pm 37.4$ \\
\hline $\mathrm{HoFeO}_{3}$ & 1364.2 & 35.98 & $1880.7 \pm 4.8$ & 300.8 & $3941.5 \pm 19.3$ \\
\hline $\mathrm{ErFeO}_{3}$ & 1400.5 & 35.98 & $1897.9 \pm 1.9$ & 317.1 & $3952.4 \pm 19.3$ \\
\hline $\mathrm{TmFeO}_{3}$ & & 27.61 & $1888.7 \pm 5.9$ & 232.2 & $4062.7 \pm 17.4$ \\
\hline $\mathrm{YbFeO}_{3}$ & & 23.43 & 1814.6 & 152.1 & $4212.6 \pm 2.5$ \\
\hline $\mathrm{LuFeO}_{3}$ & & 19.25 & 1878.2 & 427.6 & $3905.5 \pm 38.7$ \\
\hline
\end{tabular}

${ }^{\text {a }}$ all with r.m.s. devs. $= \pm 12.55 \mathrm{~kJ} \mathrm{~mol}^{-1}$; 
Table 4. Molecular $\left(\mathrm{v}_{\mathrm{m}}\right)$ and molar $\left(\mathrm{V}_{\mathrm{m}}\right)$ volumes and lattice enthalpies of lanthanide orthoferrites

\begin{tabular}{|c|c|c|c|c|c|}
\hline $\mathrm{LnFeO}_{3}$ & $\begin{array}{c}\mathrm{v}_{\mathrm{m}} / \mathbf{1 0} \mathbf{0}^{-30} \\
\mathbf{m}^{3}\end{array}$ & $\begin{array}{c}\mathrm{V}_{\mathrm{m}} / 10^{-6} \\
\mathrm{~m}^{3} \mathrm{~mol}^{-1}\end{array}$ & $\begin{array}{c}\Delta_{\mathrm{L}} \mathrm{H}^{\Theta} / \\
\mathrm{kJ} \text { mol }^{-1} \\
\text { this work }\end{array}$ & $\begin{array}{c}\Delta_{\mathrm{L}} \mathrm{H}^{\Theta} / \\
\mathrm{kJ} \mathrm{mol}^{-1} \\
\text { this work }\end{array}$ & $\begin{array}{c}\Delta_{\mathrm{L}} \mathrm{U} / \\
\mathbf{k} \mathbf{J} \mathbf{m o l}^{-1} \\
c\end{array}$ \\
\hline $\mathrm{PrFeO}_{3}$ & 59.35 & 35.74 & $13960 \pm 24$ & & 14505 \\
\hline $\mathrm{NdFeO}_{3}$ & 59.175 & 35.64 & $13997 \pm 52$ & $13994 \pm 40$ & 14519 \\
\hline $\mathrm{SmFeO}_{3}$ & 58.275 & 35.09 & $14055 \pm 54$ & $14042 \pm 40$ & 14593 \\
\hline $\mathrm{EuFeO}_{3}$ & 58.00 & 34.93 & $14104 \pm 31$ & $14108 \pm 12$ & 14616 \\
\hline $\mathrm{GdFeO}_{3}$ & 57.775 & 34.79 & $14125 \pm 39$ & $14119 \pm 20$ & 14635 \\
\hline $\mathrm{TbFeO}_{3}$ & 56.825 & 34.22 & $14175 \pm 37$ & $14163 \pm 20$ & 14716 \\
\hline $\mathrm{DyFeO}_{3}$ & 56.75 & 34.18 & $14179 \pm 55$ & $14169 \pm 38$ & 14723 \\
\hline $\mathrm{HoFeO}_{3}$ & 56.30 & 33.90 & $14223 \pm 35$ & $14199 \pm 20$ & 14762 \\
\hline $\mathrm{ErFeO}_{3}$ & 56.025 & 33.74 & $14259 \pm 34$ & $14263 \pm 20$ & 14786 \\
\hline $\mathrm{TmFeO}_{3}$ & 55.475 & 33.41 & $14272 \pm 34$ & & 14835 \\
\hline $\mathrm{YbFeO}_{3}$ & 55.275 & 33.29 & $14300 \pm 16$ & & 14853 \\
\hline $\mathrm{LuFeO}_{3}$ & 54.90 & 33.06 & $14296 \pm 52$ & & 14886 \\
\hline
\end{tabular}

${ }^{a}$ obtained with $\Delta_{\mathrm{f}, \text { ox }} \mathrm{H}^{\Theta}, \quad{ }^{\mathrm{b}}$ obtained with $\Delta_{\mathrm{f}, \mathrm{el}} \mathrm{H}^{\Theta}, \quad{ }^{\mathrm{c}}$ determined after an empirical equation of Glasser and Jenkins ${ }^{26}$

physical meaning, dimension and magnitude obtained from the slope $\left(\partial \Delta_{\mathrm{L}} \mathrm{H}^{\Theta} / \partial \mathrm{V}_{\mathrm{m}}\right)$; this slope retains a correct shear- modulus dimension: $\left[\mathrm{J} \mathrm{m}^{-3}\right]=[\mathrm{Pa}]$.

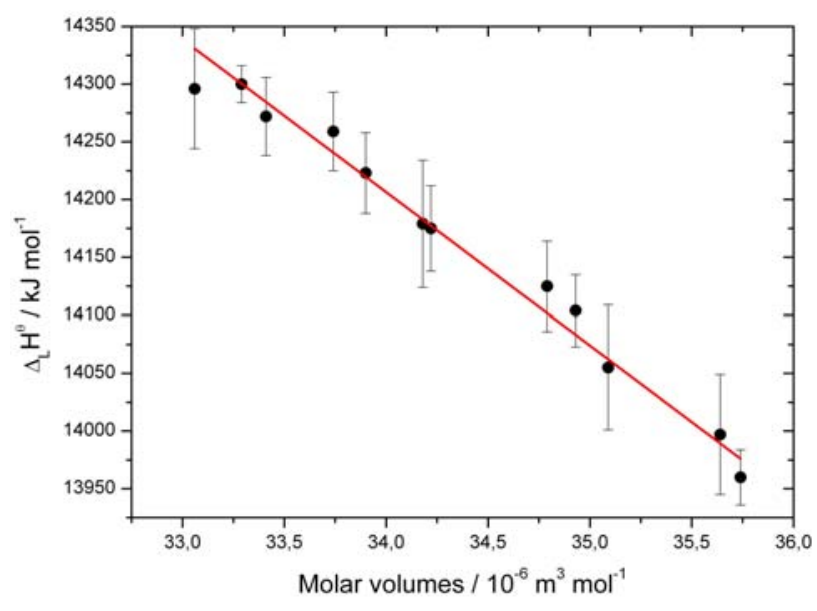

Figure 1. Variation of the lattice enthalpies vs. molar volumes of $\mathrm{LnFeO}_{3}$ with enthalpies of formation of $\mathrm{LnFeO}_{3}$ from oxides

The slope $\left(\partial \Delta_{\mathrm{L}} \mathrm{H}^{\Theta} / \partial \mathrm{V}_{\mathrm{m}}\right)$ and shear moduli have the same dimension, $[\mathrm{Pa}]$; it is obvious that a displacement of ions can be related to shear modulus. The meaning of the slope is of a critical amount of energy that, after being absorbed, will result in lattice destruction. Recent studies of the mechanical moduli of $\mathrm{NdFeO}_{3}$ by equation of state $\mathrm{V}(\mathrm{P})$ in the Birch - Mournaghan form have revealed a value of $\mathrm{E}=244 \pm 4 \mathrm{GPa}$ for the elastic (Young's) modulus ${ }^{29}$ and $\mathrm{K}=195.1 \mathrm{GPa}^{30}$ for the bulk modulus. From these experimental results we have calculated the value of the shear moduli $\mathrm{G}$ using the relationships between $\mathrm{E}, \mathrm{K}$, and $\mathrm{G}^{.23}$ the obtained value is $\mathrm{G}=94.5 \mathrm{GPa}$, which is lower than both slopes found in this work. Other reported values of mechanical moduli of $\mathrm{LnFeO}_{3}$ are close to those for
$\mathrm{NdFeO}_{3}$ : for $\mathrm{GdFeO}_{3}$, mean calculated bulk modulus $\mathrm{K}=$ $182 \mathrm{GPa},{ }^{31}$ and experimental $\mathrm{K}=204.2 \mathrm{GPa} .{ }^{30}$ The thermodynamic relations between the internal energy and the moduli of a solid have explicit forms only for crystals of simple structure and small molar volumes. ${ }^{23}$

\section{Conclusions}

The lattice enthalpies $\Delta_{\mathrm{L}} \mathrm{H}^{\Theta}$ of $\mathrm{LnFeO}_{3}$ increase linearly with decreasing the molar volumes $\mathrm{V}_{\mathrm{m}}$ within the lanthanide series and remain close to those determined after an empirical equation. The negative slope of this dependence corresponds to lattice enthalpy per molar volume and can be considered as an upper limit of the shear moduli for the series of $\mathrm{LnFeO}_{3}$. Similar relationships have been observed in our previous studies on lanthanide complex oxides. ${ }^{19-22}$

\section{Acknowledgments}

The author would like to thank Prof. B. M. Angelov for useful comments.

\section{References}

1. M. Marezio, P. D. Dernier, Mater. Res. Bull. 1971, 6, 23-29. http://dx.doi.org/10.1016/0025-5408(71)90155-3

2. Z. Zhou, L. Guo, H. Yang, Q. Liu, F. Ye, J. Alloys Comp. 2014, 583, 21-31.

3. A. Bombik, H. Böhm, J. Kusz, A. W. Pacyna, J. Magn. Magn. Mater. 2001, 234, 443-453.

http://dx.doi.org/10.1016/S0304-8853(01)00136-6

4. Y. K. Jeong, J. H. Lee, S. J. Ahn, H. M. Jang, Solid St. Commun. 2012, 152, 1112-1115. 
5. A. Bhattacharjee, K. Saito, M. Sorai, J. Phys. Chem. Solids 2002, 63, 569-574. http://dx.doi.org/10.1016/S0022-3697(01)00195-0

6. M. Siemons, U. Simon, Sensors \& Actuators B 2007, 126, 181-186. http://dx.doi.org/10.1016/j.snb.2006.11.022

7. A. Pathak, S. D. Kulkami, S. K. Date, P.Pramanik, Nanostruct. Mater. 1997, 8, 101-117. http://dx.doi.org/10.1016/S0965-9773(97)00070-6

8. M. Rajendran, A. K. Bhattacharya, J. Eur. Ceram. Soc. 2004, 24, 111-117. http://dx.doi.org/10.1016/S0955-2219(03)00267-X

9. C. Shivakumara, Solid St. Commun. 2006, 139, 165-169.

10. Ž. Dohnalová, P. Šulcová, M. Trojan, J. Thermal Anal. Calor. 2008, 91, 559-563. http://dx.doi.org/10.1007/s10973-007-8636-0

11. L. Li, X. Wang, Y. Zhang, Mater. Res. Bull. 2014, 50, 18-22. http://dx.doi.org/10.1016/j.materresbull.2013.10.027

12. M. A. Ahmed, S. I. El-Dek, Mater. Lett. 2005, 60, 14371446. http://dx.doi.org/10.1016/j.matlet.2005.11.076

13. K. Sultan, M. Ikram, K. Asokan, Vacuum 2014, 99, 251-258. http://dx.doi.org/10.1016/j.vacuum.2013.06.014

14. S. C. Parida, S. K. Rakshit, S. Dash, Z. Singh, B. K. Sen, V. Venugopal, J. Solid State Chem. 2006, 179, 2212-2230. http://dx.doi.org/10.1016/j.jssc.2006.04.024

15. S. C. Parida, S. K. Rakshit, Z. Singh, J. Solid State Chem. 2008, 181, 101-121. http://dx.doi.org/10.1016/j.jssc.2007.11.003

16. Y. Kanke, A. Navrotsky, J. Solid State Chem. 1998, 141, 424-436. http://dx.doi.org/10.1006/jssc.1998.7969

17. T. Katsura, T. Sekine, K. Kitayama, T. Sugihara, N. Kimizuka, J. Solid State Chem. 1978, 23, 43-57.
http://dx.doi.org/10.1016/0022-4596(78)90052-X

18. M. Iglesias, A. Rodriguez, P. Blaha, V. Pardo, D. Baldomir, M. Pereiro, J. Botana, J. E. Arias, K. Schwarz, J. Magn. Magn. Mater. 2005, 290-291, 396-399. http://dx.doi.org/10.1016/j.jmmm.2004.11.483

19. D. Petrov, B. Angelov, Physica B: Cond. Matt. 2012, 407, 3394-3397. http://dx.doi.org/10.1016/j.physb.2012.04.044

20. D. Petrov, Thermochim. Acta 2013, 557, 20-23. http://dx.doi.org/10.1016/j.tca.2013.01.039

21. D. Petrov, Croat. Chem. Acta 2014, 87, 85-89. http://dx.doi.org/10.5562/cca2298

22. D. Petrov, Acta Chim. Slov. 2014, 61, 34-38.

23. P. Atkins, J. De Paula, Physical Chemistry, Oxford University Press, Oxford, UK, 2006, pp. 719-722.

24. D. Lide, CRC Handbook of Chemistry and Physics, CRC Press, Boca Raton, USA, 2004, pp. 85-90.

25. C. I. Smithels, Metals Reference Book (in Russ.), Butterworths, London, UK, 1976, pp. 138-150.

26. L. Glasser, H. D. B. Jenkins, J. Am. Chem. Soc. 2000, 122, 632-638. http://dx.doi.org/10.1021/ja992375u

27. H. D. B. Jenkins, J. Chem. Educ. 2005, 82, 950-953. http://dx.doi.org/10.1021/ed082p950

28. W. C. Martin, L. Hagan, J. Sugar, J. Phys. Chem. Ref. Data 1974, 3, 771-779. http://dx.doi.org/10.1063/1.3253147

29. A. G. Gavriliuk, I. A. Troyan, R. Boehler, M. I. Eremets, I. S. Lyubutin, N. R. Serebrynaya, JETP Lett. 2003, 77, 619-624. http://dx.doi.org/10.1134/1.1600818

30. A. S. Verma, A. Kumar, J. Alloys Comp. 2012, 541, 210-214.

31. N. L. Ross, J. Zhao, J. B. Burt, T. D. Chaplin, J. Phys. Cond. Matter 2004, 16, 5721-5731. http://dx.doi.org/10.1088/0953-8984/16/32/009

\section{Povzetek}

$\mathrm{Z}$ uporabo Born-Haberjevega ciklusa smo določili mrežne entalpije, $\Delta_{\mathrm{L}} \mathrm{H}^{\Theta}$, lantanoidnih ortoferitov, $\mathrm{LnFeO}_{3}$, ter dobljene vrednosti primerjali s tistimi, dobljenimi z empiričnimi enačbami. Entalapije smo za 12 spojin določili s pomočjo podatkov za okside $\left(\mathrm{Ln}_{2} \mathrm{O}_{3}, \mathrm{Fe}_{2} \mathrm{O}_{3}\right)$, za 8 spojin pa s pomočjo podatkov za elemente, vendar je razlika v $\Delta_{\mathrm{L}} \mathrm{H}^{\Theta}$ zelo majhna. Vrednosti, dobljene s pomočjo Born-Haberjevega ciklusa se dobro ujemajo s tistimi, izračunanimi z empiričnimi enačbami Glasserja in Jenkinsa. Ugotovili smo povezavo med dimenzijami ter parcialnimi odvodi mrežnih entalpij na parcialni molski volumen ter zgornjo limito strižnega modula proučevanih spojin. 